\title{
GROWTH PERFORMANCE AND SOME MORPHOLOGICAL TRAITS OF HONAMLI GOAT KIDS UNTIL WEANING AGE IN EXTENSIVE CONDITIONS*
}

\author{
OzKan Elmaz ${ }^{1}$, Mehmet ÇOlaK ${ }^{1}$, AYKut Asim AKbaș $^{1}$, Mustafa SaAtCi $^{1}$ \\ ${ }^{1}$ Mehmet Akif Ersoy University, Faculty of Veterinary Medicine, \\ Department of Animal Science, \\ 15030, Istiklal Campus, Burdur - TURKEY \\ elmaz@mehmetakif.edu.tr
}

\begin{abstract}
* This research is a part of project supported by The Scientific \& Technological Research Council of Turkey (TUBITAK), Project No: 112R031
\end{abstract}

\begin{abstract}
The aim of this study was to determine growth performance until weaning age of Honaml goat kids reared in extensive conditions in Turkey. Study was carried out with 75 Honaml kids ( 44 female, 31 male), kept at the Research and Training Farm of the Faculty of Veterinary Medicine of Mehmet Akif Ersoy University in Burdur, Turkey.

Birth weight of male kids was higher than that female kids and also birth weight of single kids was higher than that twin kids. Live weight in the $120^{\text {th }}$ day of male, female, single and twin kids were $24.4 \mathrm{~kg}, 22.0 \mathrm{~kg}$, $26.9 \mathrm{~kg}$ and $21.2 \mathrm{~kg}$, respectively.

Withers height, body length, chest circumference and nose length on the $120^{\text {th }}$ day were detected as $61.6 \mathrm{~cm}$, $58.4 \mathrm{~cm}, 59.2 \mathrm{~cm}$ and $18.4 \mathrm{~cm}$, respectively in female Honamlı kids. Same measurements were $63.9 \mathrm{~cm}, 61.7$ $\mathrm{cm}, 62.7 \mathrm{~cm}$ and $20.0 \mathrm{~cm}$ for males Honamlı kids.
\end{abstract}

Keywords: Honamlı kids, body measurements, live weight, weaning age

\section{INTRODUCTION}

Honamlı goats are being reared by Turkish nomads in Antalya, Burdur and Isparta cities (Teke yöresi), located of the Taurus Mountains in the Mediterranean region of Turkey. The most of $(97 \%)$ goats are Hair goat (K1l goats) in Turkey. While the number of goats in Turkey in 2005 was 6517 464, in 2015 it was 10416 166. (TURKSTAT, 2015).

Honamlı goat by the authorities of the Ministry of Agriculture have registered as a new breed. Honamlı goat has a big body and long legs. The bottom jaw bone is longer than the top jaw bone (undershot jaw or monkey mouth). Its eye are clearly big and vivacious. Ears are small and thick. Nose is clearly convex. It is a submissive breed and so familiar and submissive (GDARP, 2009).

\section{MATERIAL AND METHOD}

Study was carried out with 75 Honamlı kids (44 female, 31 male), kept at the Research and Training Farm of the Faculty of Veterinary Medicine of Mehmet Akif Ersoy University in Burdur, Turkey. The flock was pastured on open range fields and forests from early in the morning until noon. Then the flock rested in a shaded area during noon and in the afternoon they continued to graze when the effect of the heat disappeared. In the evening the flock returned to their folds. In general, this district is poor in terms of amount and quality of pasture. Kids were suckling in the morning and at night and when they were 3 months old started to go out to the graze with their dams. The kids' weaning age was 120 
days old. The live weights of the kids on the birth weight, $60^{\text {th }}$ and $120^{\text {th }}$ day were recorded. Live weights (LW) of kids were taken with sensitive scales up to $50 \mathrm{~g}$ at morning. Withers height, body length, chest circumference and nose length on the $60^{\text {th }}$ and $120^{\text {th }}$ day of kids were measured.

Descriptive statistics of the live weight and body measurements were determined by using Minitab version 12.0 software ANOVA GLM procedure (MINITAB, 2011).

\section{RESULTS}

Birth weight of male kids was higher than that female kids and also birth weight of single kids was higher than that twin kids. Birth weights of male, female, single and twin kids were $4.4 \mathrm{~kg}, 4.1 \mathrm{~kg}, 4.8 \mathrm{~kg}$ and $4.0 \mathrm{~kg}$, respectively. Live weight, withers height, body length, chest circumference and nose length on the $120^{\text {th }}$ day were detected as $22.0 \mathrm{~kg}, 61.6$ $\mathrm{cm}, 58.4 \mathrm{~cm}, 59.2 \mathrm{~cm}$ and $18.4 \mathrm{~cm}$, respectively in female Honamli kids. Same measurements were $24.4 \mathrm{~kg}, 63.9 \mathrm{~cm}, 61.7 \mathrm{~cm}, 62.7 \mathrm{~cm}$ and $20.0 \mathrm{~cm}$ for males Honaml kids.

Table 1. Mean live weight in the different periods according to sex of Honamlı kids

\begin{tabular}{ccccccc}
\multicolumn{8}{c}{$(\mathbf{k g})\left(\overline{\boldsymbol{x}} \pm \boldsymbol{S}_{\bar{x}}\right)$} \\
\hline & $\mathbf{n}$ & $\begin{array}{c}\text { Birth } \\
\text { weight }\end{array}$ & $\mathbf{n}$ & $\mathbf{6 0}^{\text {th }}$ day & $\mathbf{n}$ & $\mathbf{1 2 0}^{\text {th }}$ day \\
\hline Female & $\mathbf{4 4}$ & $4.1 \pm 0,09$ & $\mathbf{4 4}$ & $13,1 \pm 0,35$ & $\mathbf{4 4}$ & $22,0 \pm 0,56$ \\
Male & $\mathbf{3 1}$ & $4,4 \pm 0,13$ & $\mathbf{3 1}$ & $14,4 \pm 0,66$ & $\mathbf{3 1}$ & $24,4 \pm 1,18$ \\
Overall & $\mathbf{7 5}$ & $4,2 \pm 0,08$ & $\mathbf{7 5}$ & $13,6 \pm 0,35$ & $\mathbf{7 5}$ & $23,0 \pm 0,60$ \\
\hline
\end{tabular}

Table 2. Mean live weight in the different periods according to birth type of Honaml kids (kg) $\left(\bar{x} \pm s_{\bar{x}}\right)$

\begin{tabular}{ccccccc}
\hline & $\mathbf{n}$ & $\begin{array}{c}\text { Birth } \\
\text { weight }\end{array}$ & $\mathbf{n}$ & $\mathbf{6 0}^{\text {th }}$ day & $\mathbf{n}$ & $\mathbf{1 2 0}^{\text {th }}$ day \\
\hline Single & $\mathbf{2 3}$ & $4,8 \pm 0,12$ & $\mathbf{2 3}$ & $16,1 \pm 0,69$ & $\mathbf{2 3}$ & $26,9 \pm 1,19$ \\
Twin & $\mathbf{5 2}$ & $4,0 \pm 0,08$ & $\mathbf{5 2}$ & $12,5 \pm 0,29$ & $\mathbf{5 2}$ & $21,2 \pm 0,54$ \\
Overall & $\mathbf{7 5}$ & $4,2 \pm 0,08$ & $\mathbf{7 5}$ & $13,6 \pm 0,35$ & $\mathbf{7 5}$ & $23,0 \pm 0,60$ \\
\hline
\end{tabular}

Table 3. Mean \pm SE body measurements of Honamlı kids in different ages (60 and 120

\begin{tabular}{ccccccc} 
Age (day) & Sex & $\mathbf{n}$ & $\begin{array}{c}\text { Withers Height } \\
(\mathbf{c m})\end{array}$ & $\begin{array}{c}\text { Body Length } \\
(\mathbf{c m})\end{array}$ & $\begin{array}{c}\text { Chest } \\
\text { Circumference } \\
(\mathbf{c m})\end{array}$ & $\begin{array}{c}\text { Nose } \\
\text { Length } \\
(\mathbf{c m})\end{array}$ \\
\hline $\mathbf{6 0}^{\text {th }}$ day & Female & $\mathbf{4 4}$ & $54,4 \pm 0,39$ & $52,4 \pm 0,38$ & $50,6 \pm 0,42$ & $17,1 \pm 0,14$ \\
& Male & $\mathbf{3 1}$ & $55,3 \pm 0,57$ & $52,9 \pm 0,62$ & $52,1 \pm 0,74$ & $17,5 \pm 0,21$ \\
& Overall & $\mathbf{7 5}$ & $54,8 \pm 0,33$ & $52,6 \pm 0,34$ & $51,2 \pm 0,40$ & $17,3 \pm 0,12$ \\
$\mathbf{1 2 0}^{\text {th }}$ day & Female & $\mathbf{4 4}$ & $61,6 \pm 0,51$ & $58,4 \pm 0,48$ & $59,2 \pm 0,50$ & $18,4 \pm 0,17$ \\
& Male & $\mathbf{3 1}$ & $\mathbf{6 3 , 9} \pm 0,80$ & $61,7 \pm 0,93$ & $62,7 \pm 0,90$ & $20,0 \pm 0,35$ \\
& Overall & $\mathbf{7 5}$ & $62,6 \pm 0,46$ & $59,8 \pm 0,51$ & $60,7 \pm 0,51$ & $19,1 \pm 0,19$ \\
\hline
\end{tabular}




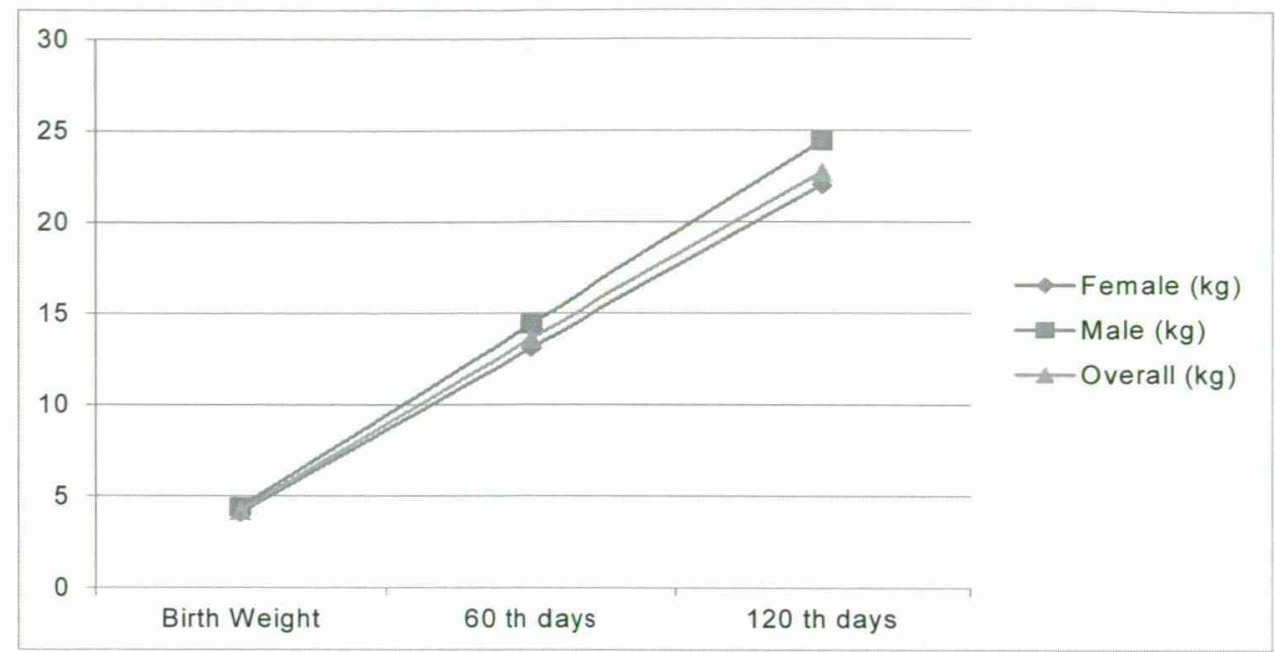

Figure 1. Mean live weight in the different periods according to sex of Honamlı kids

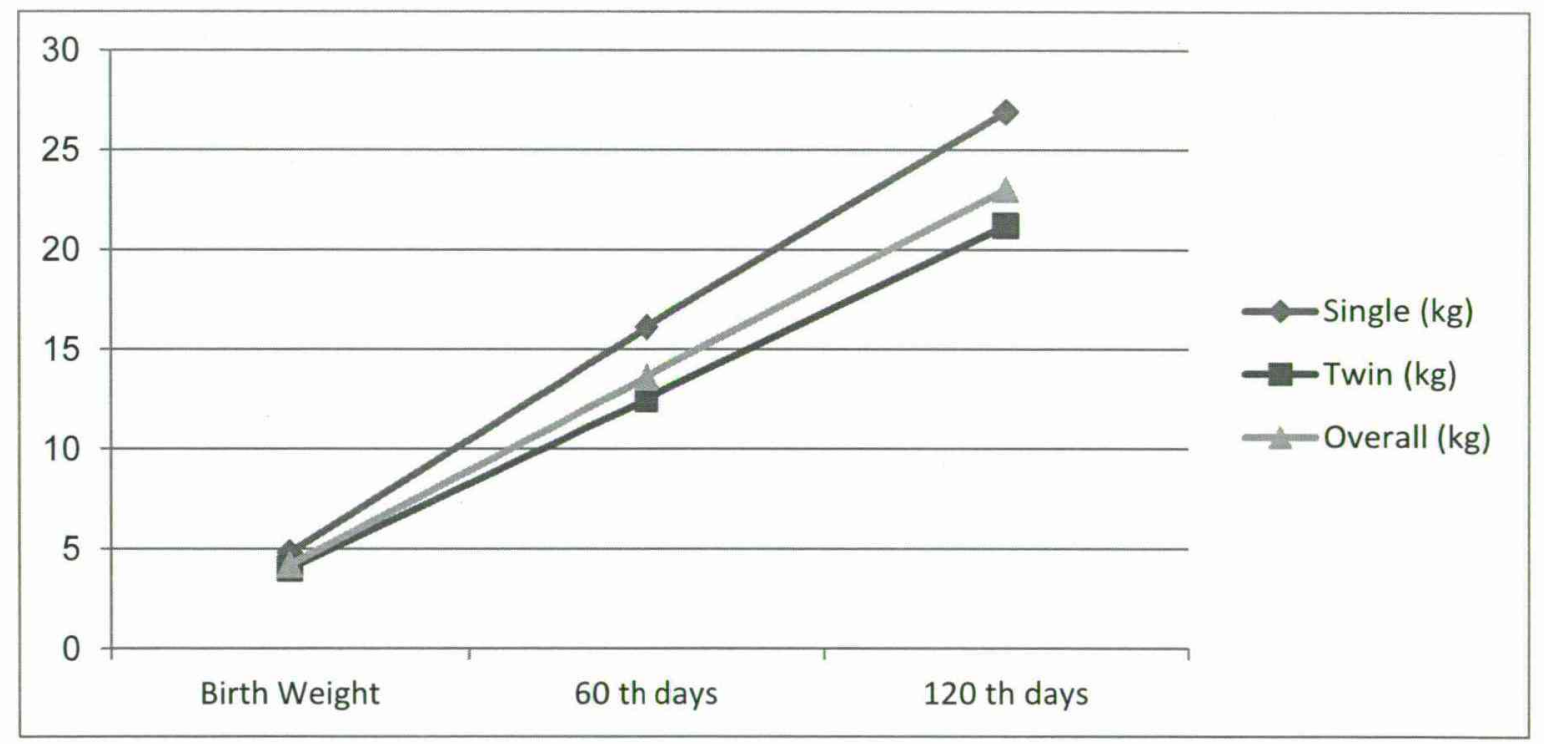

Figure 2. Mean live weight in the different periods according to birth type of Honaml kids

\section{CONCLUSIONS}

The birth weight and live weights on the 120th days of Honamli kids were higher than the Hair kids in Turkey (ŞENGONCA ET AL., 2003; ŞiMŞEK AND BAYRAKTAR, 2006; ORAL AND Altinel, 2006). Siwty days live weight of Honamlı kids stated by ELMAZ ET AL., (2012) were heavier than the corresponding study. ŞIMŞEK AND BAYRAKTAR (2006) reported that the withers heights of the K1l and Saanen $\mathrm{x} \mathrm{K} 1 \mathrm{l}\left(\mathrm{F}_{1}\right)$ crossbred kids on were $44.6 \mathrm{~cm}$ and $45.5 \mathrm{~cm}$, the body lengths were $43.0 \mathrm{~cm}$ and $43.4 \mathrm{~cm}$, on the $90_{\text {th }}$ day. These values were lower than the values obtained in this study. Body measurements of the Honamli kids determined by this study were higher than the values reported by the literature. 


\section{ACKNOWLEDGEMENTS}

This research is a part of project supported by The Scientific \& Technological Research Council of Turkey (TUBITAK), Project No: 112R031.

\section{REFERENCES}

Elmaz, O., SaAtci, M., DaĞ, B., Aktaş, A.H., Ata, A., Gulay, M.Ş., Mamak, N., GoK, B. (2012): Some descriptive characteristics of a new goat breed called Honamli in Turkey. Trop Anim Health Prod 44: 1913-1920.

GDARP (General Directorate of Agricultural Research and Policies) (2009): Domestic Animal Genetic Resources in Turkey, Ankara. pp. 82-83.

MinitAB, 2011. Minitab For Windows Version Release 16, Minitab Inc.

Oral, H.D., Altinel, A. (2006): Aydın ili özel işletme koşullarında yetiştirilen Kıl keçilerinin bazı verim özellikleri arasındaki fenotipik korelasyonlar. (in Turkish, with English abstract). İstanbul Üniversitesi Veteriner Fakültesi Dergisi 32(3): 41-52.

ŞENGONCA, M., TASkIn, T., Kosum, N. (2003): Saanen x Kıl keçi melezlerinin ve saf Kıl keçilerinin kimi verim özelliklerinin belirlenmesi üzerine eş zamanlı bir araştırma. (in Turkish with English abstract). Turk Journal Veterinary Animal Science 27(6): 1319-1325. ŞimŞEK, Ü.G., BAYRAKTAR, M. (2006): K11 keçisi ve Saanen x Kıl keçisi (F1) melezlerine ait büyüme ve yaşama gücü özelliklerinin araştırılması. (in Turkish, with English abstract). Furat Üniversitesi Sağlık Bilimleri Dergisi 20(3): 229-238.

TuRKstat (Turkish Statistics Institute), (2016): The Results of Animal Production Statistics, http://www.tuik.gov.tr/UstMenu.do?metod=temelist (accessed 17.02.2016). 